\title{
INFLUENCE OF MASS BALANCE AND RUN-OFF ON RELIEF-FORMING ACTIVITY OF MOUNTAIN GLACIERS
}

\author{
by \\ L. P. Chernova \\ (Institute of Geography, Academy of Sciences U.S.S.R., Staromonetny per. 29, \\ Moscow 109017, U.S.S.R.)
}

\section{ABSTRACT}

Experimental data from several Soviet authors are used to investigate the importance of relief-forming processes in a glacial environment. Water discharge from glacial rivers was found to be crucial for the evolution of frontal moraines versus pro-glacial glaciofluvial deposits (sandar and valley trains).

\section{DISCUSSION}

Insufficient attention has been paid to assessing the relative roles of glaciers and cl imate in glacial erosion and sedimentation. The work of Litvin (unpublished) and Machavariani (unpubl ished), for example, demonstrates the predominant effects of climatic factors over lithology for the formation of certain morphological features in medium-high mountainous areas.

In this brief report, the relative roles of glaciers and associated melt-water run-off (both controlled by precipitation in the glacier basin) in the sediment budget of the immediate pro-glacial zone are examined. Both temperature and solid precipitation on mountain glaciers of temperate latitudes vary widely. Average summer temperatures at the equilibrium 1 ine vary from glacier to glacier but are between -5 and $+8^{\circ} \mathrm{C}$. Similarly, precipitation varies greatly between 0.1 and $5 \mathrm{~m}$. Thus, a difference by a factor of 50 may exist in the annual ablation volume for two glaciers of equal area. Earlier investigations in the Caucasus showed that there was direct correlation between size of corries and mass ice flux of occupying glaciers. According to calculations (Krenke and Khovanskiy 1973), ice discharge is directly proportional to snow precipitation so that, with increased atmospheric precipitation in a glacier basin, glacial erosion becomes more intense. Erosional ability of the river flowing out from the glacier is similarly increased. These relationships are clearly important for assessing the glaciofluvial sediment budget of the pro-glacial zone.

Soviet opinion supports the belief that a negative or positive balance is affected by the advance or retreat of the glacier. During glacier advance, melt-water drainage is small, sediment discharge is also small, and deposition of frontal moraine increases. When glaciers are retreating, water discharge is usually high and the river will wash out and remove much of the frontal moraine. This conclusion, however, conflicts with data on oceanic sedimentation. Degens and Ross (1972) show that bathypelagic deposition in the BTack Sea reached $1 \mathrm{~mm} \mathrm{a}^{-1}$ during the wirm glacial period but fell to $0.1 \mathrm{~mm} \mathrm{a} \mathrm{a}^{-1}$ during the post-Würm period. Shumm (1968) also noted a decrease by 2.4 in the deposition rate on the Atlantic continental shelf at the end of the last glacial.

The existence of considerable quantities of non-consolidated sediments in the upper parts of glacial river systems clearly demonstrates that transport dominates over river erosion within the time scale of hundreds of years. Observational data from glaciers in Central Asia (Table I) provide verification of maximum deposition close to the glacier terminus during periods of glacier recession. The data were compiled by the author from the results of field investigations of Sadykov (unpubl ished), who related annual sediment budget of moraines to pro-glacial river discharge. The quantity of sediment removed by washingout is from 23 to $90 \%$ of sediment income. The results demonstrate net accumulation of sediment in the immediate pro-glacial zone even during times of glacier recession during the 20th century.

The volume of deposits for the largest glacier is about two thousand times larger than for the smallest whereas the corresponding volume of eroded material differs by about three thousand times. Thus the volume of material deposited at the end of the largest glacier is only 70 times greater than that for the smallest. It appears that glacial erosion by rivers at the termini of glaciers with small discharge is so weak that about $50 \%$ of the material brought down by the ice remains at the snout. For glaciers with a high melt-water discharge, up to 80 to $95 \%$ of icetransported material may be removed.

Morphologically these processes manifest themselves in the creation of large frontal moraines at the termini of glaciers discharging only small quantities of water (Fig. 1). Furthermore, as there is a strong positive relationship between precipitation, glacier erosion, transporting ability, and pro-glacial run-off, those glaciers receiving most solid precipitation will not only carry more debris to the snout but the removal of this debris by pro-glacial rivers will also be the largest. The process results in those glaciers with most solid precipitation in their basins transporting large quantities of debris to the snout, but accumulation of sediment in the form 
TABLE I. ANNUAL SEDIMENT BUDGET FOR SEVERAL GLACIERS IN CENTRAL ASIA (from Sadykov, unpublished)

\begin{tabular}{|c|c|c|c|c|c|c|}
\hline Glacier & $\begin{array}{c}(1) \\
\text { Glacier } \\
\text { area }\end{array}$ & $\begin{array}{l}\text { (2) } \\
\text { Unconsolidated } \\
\text { sediments } \\
\text { transported } \\
\text { to glacier } \\
\text { terminus }\end{array}$ & $\begin{array}{c}(3) \\
\text { Increase } \\
\text { in mora ine } \\
\text { volume }\end{array}$ & $\begin{array}{l}\text { (4) } \\
\text { Sediments } \\
\text { removed by } \\
\text { glacial river }\end{array}$ & $\begin{array}{c}(5) \\
\text { Balance } \\
\text { between } \\
2 \text { and } 3\end{array}$ & $\begin{array}{c}(6) \\
\text { Glacial } \\
\text { river } \\
\text { discharge }\end{array}$ \\
\hline & $\mathrm{km}^{2}$ & $10^{6} \mathrm{~kg} \mathrm{a}^{-2}$ & $10^{6} \mathrm{~kg} \mathrm{a}^{-1}$ & $10^{6} \mathrm{~kg} \mathrm{a}^{-1}$ & $(\%)$ & $10^{6} \mathrm{~m}^{3} \mathrm{a}^{-1}$ \\
\hline $\begin{array}{l}\text { Fedchenko } \\
\text { (1925-1959 } \\
\text { average) }\end{array}$ & 662 & 8300 & 500 & 7800 & 94 & 1000 \\
\hline $\begin{array}{r}\text { Zaravshanskiy } \\
(1850-1932)\end{array}$ & 134 & 2200 & 400 & 1800 & 82 & 476 \\
\hline RGO (1911-1935) & 109 & 1100 & 260 & 940 & 87 & 306 \\
\hline IMAT $(1963-1968)$ & 3.8 & 15.4 & 6.9 & 8.5 & 55 & 12 \\
\hline $\begin{array}{l}\text { Ajutor-3 } \\
\qquad(1935-1970)\end{array}$ & 3.4 & 9.6 & 7.4 & 2.2 & 22 & 10 \\
\hline $\begin{array}{l}\text { Karabatkak } \\
(1935-1949)\end{array}$ & 4.7 & 13.6 & 8.8 & 4.8 & 35 & 8 \\
\hline
\end{tabular}

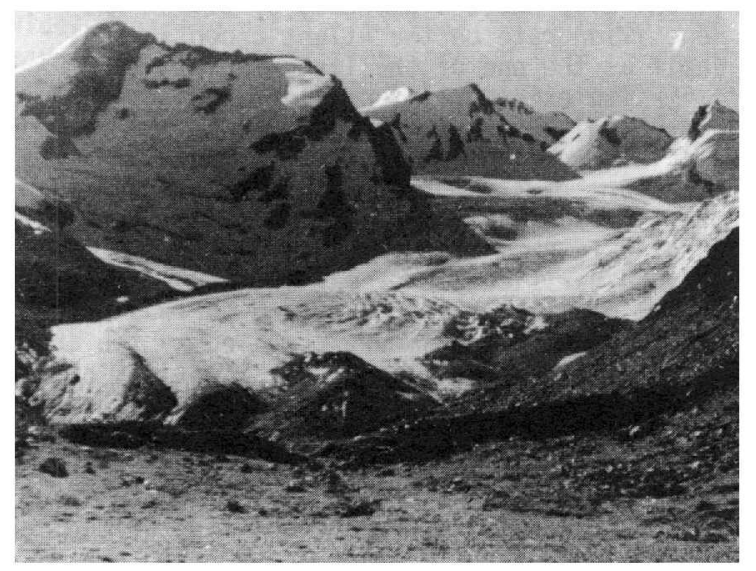

Fig.1. Glaciofluvial plain at the terminus of lednik Dzhankuat. The small frontal moraine was evidently not subjected to washing out and is strongly pronounced. High lateral moraines may be seen.

of moraine is prevented by the equally high discharge of melt-water streams.

This type of dependence suggests that the advance of glaciers caused by general climate cooling will lead to the creation of high frontal moraines. Glaciofluvial outwash plains, however, wi 71 form when glacier advance is triggered by increase in precipitation.

\section{REFERENCES}

Degens E T, Ross D A 1972 Chronology of the Black Sea over the last 25,000 years Chemical Geology 10(1): 1-16

Krenke A N, Khovanskiy G S 1974 Raschyet protyazhennosti zon 1 'doobrazovaniya na lednikakh $v$ nestatsionarnykh us loviyakh [Calculation of duration of glacier formation zones on glaciers under non-steady conditions]. Materialy Glyatsiologicheskikh Issledovaniy. Khronika. Obsuzhdeniya 23: 25-34
Litvin L F Unpublished. Razvitiye protsessov erozii $\vee$ gornykh usloviyakh [The development of erosion processes in mountain conditions]. (Abstract of dissertation of candidate of geographical sciences, Moscow, 1970)

Machavariani N G Unpublished. Stok vzveshennykh nanosor rek yuzhnogo sklona Tsentral 'nogo Kavkaza [Drainage of suspended al luvium of rivers of the southern slopes of the central Caucasus]. (Abstract of dissertation of candidate of geographical sciences, Tbilisi, 1970)

Sadykov K G Unpublished. Balans moren, tverdyy stok i rel'yefoobrazuyushchaya deyate 1 'nost' sovremennykh lednikov Sredney Azi $i$

[Balance of moraines, solid run-off and relief-forming activity of present glaciers of Central Asia]. (Abstract of dissertation of candidate of geographical sciences, Moscow, 1975)

Shumm S 1968 Paleogidrologiya chetvertichnogo perioda - chetvertichnyy period v SShA. Tom 1 [Palaeohydrology of the Quaternamy period - the Quatemary period in the U.S.A. Vot 1]. Moscow, "Mir" 